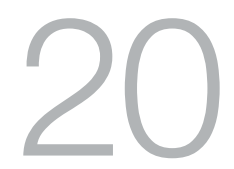

\title{
Everyday Acts of Resurgence and Diasporic Indigeneity among the Ainu of Tokyo
}

\author{
Kanako Uzawa
}

\section{Introduction}

'To stand on the same platform as Wajin, we need an education.' These words were spoken to me by Tadashi Kaizawa, who fought for Ainu rights as an activist, farmer, writer and one of the leaders of the Nibutani Ainu community in Hokkaidō. He was not only my grandfather, but also an educator who taught us important values in life. Sadly, he was not able to receive the education he wished for, so his determination to provide a good education for his children led all three of them to pursue a university education. Later, his youngest daughter, my mother, became a school teacher in Tokyo, and married my Wajin father. During my teenage years, I understood how important it was for me to receive a higher education in order to become an independent Ainu woman. Through my difficult years in a strict Japanese education system, I always thought of my grandfather, and held on to all my living memories of nature, the smell of the forest and the vivid life of the Nibutani community where I spent all the school holidays with my family. Even though I did not live permanently in Nibutani, I felt it was my home, and considered it so. Tokyo gave me a feeling of disconnection from Ainu culture-that was until I encountered the Tokyo Ainu community. 
This article is a reflection on stories from my youth, when I became aware of what it means to be Ainu in Tokyo, and how my experiences of living in both Nibutani and Tokyo affect my daily life as an urban Indigenous person. From the outset, I would like to thank all members of the Ainu Association of Rera ${ }^{1}$ in Tokyo who accepted me for who I am and supported me in pursuit of my own path as an urban Ainu. All the experiences I have shared with the Ainu community in Tokyo made me realise how important it is to document and share our life stories and events as urban Ainu, for the further development of Indigenous studies. I perceive this to be my Indigenous pathway, where I can contribute my Ainu perspective for both academic audiences and Indigenous communities of the world.

In this article I use the term Wajin to refer to the ethnic Japanese or non-Ainu, to clarify the point that having Japanese citizenship does not define our ethnicity. Ainu today have the same lifestyle as other Japanese citizens, both in cities and rural areas. They have Japanese as a mother tongue and are enrolled in Japanese public schools. Many Ainu migrate to cities for better employment opportunities, and sometimes to escape from discrimination. Given these similarities, the issues identifying how many Ainu there are in Japan, and how many of them live in cities, are complex, partly because Japan does not collect data on ethnicity in the national census. However, a number of surveys help to fill this gap.

According to the Advisory Council for Future Ainu Policy (2009: 16), the Hokkaidō prefectural government has conducted a survey of the Ainu population of Hokkaido almost every seven years since 1972. The aim of the survey has been to have a better understanding of the living and educational conditions of Ainu in Hokkaidō (Advisory Council for Future Ainu Policy 2009: 16). ${ }^{2}$ In terms of Ainu living outside of Hokkaidō, the most recent Ainu Living Conditions outside of Hokkaidō Survey was conducted nationwide in 2011 by the Japanese central government (Council for Ainu Policy Promotion Working Group 2011). There have been two other surveys on Ainu people living outside of Hokkaidō - in 1974 and 1988 (Watson 2014a: 69) — though these surveys, by the Tokyo Metropolitan Government, focused only on the Tokyo metropolitan area. According to the latest report from the Hokkaido Ainu Living Conditions

1 Rera means wind in Ainu.

2 The 2009 report states that the Hokkaido Ainu Living Conditions Survey was also conducted by the Hokkaidō University Center for Ainu and Indigenous Studies in 2008 (Advisory Council for Future Ainu Policy 2009: 16). 
Survey in 2017, the Ainu population in Hokkaidō consisted of 13,118 individuals in 5,571 households across 63 municipalities (Department of Hokkaidō Environment and Lifestyle 2017: 3). Ainu in Tokyo suggest there could be as many as 10,000 living in and around the capital region (Watson 2014a: 69). Although a significantly high number, Ainu use this figure to compensate for undercounting in existing statistics from metropolitan government surveys, which reported a population of 679 in 1974, and 2,699 in 1988 (Watson 2014a: 69).

This article looks at the city as a site for cultural resurgence and revitalisation amongst the Ainu in the final decades of the twentieth century. In writing of these phenomena I position myself as an Ainu researcher and include my own experiences as a member of the Tokyo Ainu community. I refer to those who live around the greater Tokyo and Kantō region as 'Tokyo Ainu'.

Many Indigenous people now define urban space as home. A report by the United Nations Department of Economic and Social Affairs (2014: 2) projects that 66 per cent of the world's population will be living in urban areas by 2050. If one considers the situation of Indigenous people in this overwhelmingly urban future, it may no longer be feasible to define us solely as remaining in our rural ancestral homelands. In urban contexts, social spaces such as schools, community centres, exhibition halls and public institutions may symbolise Indigenous culture and become transformative spaces that provide opportunities for expressing and developing Indigenous culture.

For some, a focus on Indigenous people in cities may seem inappropriate. City people who identify as Indigenous might be perceived as 'out of place' in the urban context. Yet Indigenous migration to cities has become more common in recent years. In this article, I investigate the disparity between modern Indigenous lifestyles and stereotypes of Indigenous people that are fixed in place. I explain how this disparity deeply affects the identity formation of Indigenous people in urban settings. Mark Watson (2014b) uses the term 'diasporic indigeneity' to suggest that Indigenous people often remake their identities in cities through processes of reterritorialisation, bringing lived relationships with ancestral homelands and community members into urban contexts. In considering these issues, I offer a detailed case study of one particular cultural organisation in Tokyo and explore how, within a diasporic context, self-fashioning operates within urban Ainu life. 
The analysis for this article is based on auto-ethnography. I reflect upon my own life experiences both in Tokyo, and in the rural Ainu community of Nibutani, in Hokkaidō. Paul Whitinui (2014: 458) argues that an individual's ability to explore, discover and narrate oneself as an Indigenous person is significant, and that such narrations help articulate some of the reasons why Indigenous worlds are culturally and politically different. In my case, positioning myself as an Ainu researcher and using auto-ethnography helps me to locate myself within academia and assists me in the ongoing process of negotiating how my culture should be presented to the academy and to society. In addition, auto-ethnography allows me to recognise and reconnect my past to the present and to the future by enabling me to share my experiences and knowledge as an Indigenous person who is trying to position herself in the world. What I share in this article is not Ainu traditional knowledge, but rather my memories, daily acts and experiences that have taught me to reconnect myself to Ainu culture. This is my interpretation of diasporic indigeneity and everyday acts of resurgence. By focusing on these aspects of Ainu life, I hope to provide a more current interpretation of Ainu culture, history and politics.

There are three main sections in this chapter. In the first, the enforced resettlement of Ainu from Hokkaidō to the Tokyo region and our involvement in international Indigenous politics are explored. In the second section I describe historical events leading up to the resurgence of Ainu cultural identity in the late-twentieth century. In this section, the analytical concept of 'diasporic indigeneity' comes to life through an examination of the literature. The concept of 'everyday acts of resurgence' (Corntassel 2012) is also discussed, in the context of the Tokyo Ainu community. This is followed in the third section by a more detailed enquiry of the recent historical emergence of Ainu cultural organisations in Tokyo, which, I argue, has led to the development of 'diasporic indigeneity' as an accepted form of cultural identity amongst the Ainu. In my conclusion I briefly speculate on a possible future for Ainu cultural identity. 


\section{Tokyo Ainu: Indigenous people in a Japanese city}

Watson (2014a: 76) traces the origins of the Tokyo Ainu community to the early 1950s, when Ainu migration to cities became more common. As stated above, an estimated population of Kantō-region Ainu was about 10,000 people in 2014. According to the Ainu Living Conditions outside of Hokkaido Survey in 2011, which had 210 respondents, 50 per cent answered that they had moved away from Hokkaidō to find work, and 11.4 per cent stated that their relocation was because of discrimination (Council for Ainu Policy Promotion Working Group 2011: 27).

For most of my childhood I was raised around Tokyo. I always had a feeling of loneliness and isolation because I was not able to share who I was and where my family came from. I was often seeking a safer place to rest my mind. At the age of 20, two significant events changed my life. The first was the start of my involvement in international Indigenous politics, which I discuss below. The second was that I was introduced to Tokyo's 'Ainu hub' - an Ainu restaurant in the city. This became a place where I could feel 'at home' or in a 'resting place'. It also became my cultural place of learning. By becoming more involved with the Ainu community in Tokyo, I also began to take a more active role in international Indigenous politics. Spending time with Tokyo Ainu opened my eyes and made me realise how much some of them suffered financially and sometimes psychologically. But, at the same time, I also saw how they generously welcomed new members into their community, as well as people who were interested in Ainu culture. What was most striking about my encounter with Tokyo Ainu was to learn that they still passed on and learnt Ainu culture, even though many of them had kept their Ainu identity private for many years. This raised many questions within me, and helped me to become who I am now.

It is generally known within the Tokyo Ainu community that we Ainu have migrated from Hokkaidō to cities more or less out of necessity, to pursue better employment or educational opportunities, or to escape from severe discrimination in Hokkaidō. Ainu have faced many challenges in establishing ourselves in Tokyo. Migration to Tokyo might entail a person securing a job and financial security for their family, but that does not necessarily mean they earn a high income. Through my experiences with Tokyo Ainu, I have observed that the social gap between most Ainu and 
Wajin in Tokyo is more noticeable than between Wajin, especially in the older generation. Identity is a sensitive topic, both at home and in public. These sensitivities around identity, and the social distance between Ainu and Wajin in Tokyo emerge from the Japanese state's assimilationist past and continued refusal to recognise the Ainu people as Indigenous.

In 1899, the Hokkaidō Former Aborigines Protection Act was enacted by the Japanese Government. Its aim was to assimilate Ainu into modern Japanese imperial subjects by eliminating Ainu language, values and customs (Siddle 1996: 70). In 1997, this law was replaced by the Ainu Cultural Promotion Act (CPA), which many Ainu were dissatisfied with, as it was limited only to the promotion of Ainu culture and language, and did not include recognition of our status as Indigenous people. In September 2007, when the government of Japan voted 'yes' to the United Nations Declaration on the Rights of Indigenous Peoples (UNDRIP), it still continued to refuse recognition for the Ainu as an Indigenous people of Japan according to the standards of international law. On 6 June the following year there was a major political shift within Indigenous politics in Japan. Both houses of the Japanese Diet passed a resolution calling for the recognition of the Ainu as an Indigenous people of Japan. Despite this, the government has still not, at the time of writing, included recognition of Ainu rights as an Indigenous people of Japan.

The Ainu political movement to redress this situation goes beyond the nation. Since the 1980s, Ainu organisations have been active in international Indigenous conferences such as those held by the United Nations. ${ }^{3}$ Tokyo Ainu organisations have also played a role in international Indigenous politics, aiming to present the situations and struggles of Tokyo Ainu, especially because the general public in Japan seems to know very little about the Ainu in Tokyo, and assume that Ainu reside only in Hokkaidō. This limited understanding of Tokyo Ainu could be part of the reason why there have been so few government surveys on Ainu living outside of Hokkaidō. However, as I am Tokyo Ainu myself, I know that there is a Tokyo Ainu population, and that there is an Ainu community in Tokyo.

3 The first time an Ainu organisation participated at a United Nations conference was in 1987. The organisation was the Ainu Association of Hokkaidō, the most politically involved and largest Ainu organisation in Japan (Ainu Association of Hokkaidō 2018). 
My involvement in international Indigenous politics started in 2001 when I participated in the 19th session of the UN Working Group on Indigenous Populations in Geneva, Switzerland (Ainu Association of Rera 2001) where I presented the Nibutani Dam case as a community member. This was my first attendance at a UN meeting. To be able to present at the UN, other Ainu friends in Tokyo and I were encouraged and trained by Japanese experts specialising in international law and politics. I was about 20 years old at the time. We met frequently for study groups at a café and at the Ainu Culture Center in Tokyo. ${ }^{4}$ As I was quite young and inexperienced and did not know anything about international Indigenous politics, this study was overwhelming. In the beginning, all those UN systems, terms and international laws seemed so far away from my reality that I did not grasp what I was doing. Slowly but surely, I began to understand how I might be able to contribute this knowledge to my Ainu community. This encouraged me to take an active role in international Indigenous politics later on.

On 21 May 2007, some members of the Ainu Resource Centre and I presented a joint statement together with the Shimin Gaikou Centre-a Japanese NGO and long-term supporter of the Ainu political movement - at the 6th session of the United Nations Permanent Forum on Indigenous Issues in New York (Ainu Resource Centre and Shimin Gaikou Centre 2007). ${ }^{5}$ This was only a year before the Japanese Government adopted the Resolution on Recognition of Ainu as Indigenous People on 6 June 2008 (Advisory Council for Future Ainu Policy 2009: 1). The item of the day was urban Indigenous peoples and migration. The statement (Ainu Resource Centre and Shimin Gaikou Centre 2007) described the situation for Tokyo Ainu living in the large and densely populated Kantō region, explaining how they had begun to organise themselves, and discussed how different Ainu organisations started to appear. As of 2007, there were four active Ainu associations in the Kantō region, who worked collectively under the name of Ainu Utari Renrakukai (Ainu Companions Liaison Group) when shared political agendas were in need of further discussion with the Tokyo Metropolitan Government. On this occasion,

4 The Ainu Culture Center is run by The Foundation for Research and Promotion of Ainu Culture, see www.frpac.or.jp/web/english/details/history-of-the-foundations-establishment.html (accessed 8 August 2018).

5 6th session of the United Nations Permanent Forum on Indigenous Issues, Special Theme: Territories, Lands and Natural Resources, 14-25 May 2007. 
four of the requests to the Tokyo Government raised by those associations since 1970s were presented (Ainu Resource Centre and Shimin Gaikou Centre 2007: 1-2). They were:

1. to create a place where Ainu could gather and transmit culture such as an Ainu community centre;

2. to set up social welfare support for Ainu;

3. to have an Ainu social counsellor;

4. to conduct a survey on Ainu social and economic conditions in order to have a comprehensive understanding of the Ainu.

Furthermore, the Ainu Living Conditions outside of Hokkaido Survey in 2011 shows three major needs raised by survey participants in response to what needs to be done to increase participation in and practise of Ainu culture and traditions:

1. to establish a place where we can learn;

2. to be informed about any Ainu related activities;

3. to be able to feel more relaxed about our financial situation (Council for Ainu Policy Promotion Working Group 2011: 24).

This survey indicates that Tokyo Ainu could benefit from having a common place. This would ideally be run by the Ainu ourselves with Ainu participation in all aspects of its development. The Ainu Culture Center in Tokyo provides space for activities, but participation is limited because it is managed by the state.

Another challenge that Tokyo Ainu face is that we have to take any available jobs to make a living. Often such jobs require so much time and physical effort that it is nearly impossible to engage in any Ainu cultural activities in the evening or on weekends. I remember wondering, 'How can we learn and develop our culture freely when our day jobs limit our capacity both psychologically and physically?' Tokyo Ainu are in a great need of a place and space where everybody is welcomed to participate in Ainu activities, and such a place should be run on our terms. As discussed below, the Ainu restaurant, Rera Cise (now closed), previously provided such possibilities, but the existence of such an institution is tied to its financial success, and such an institution therefore does not provide a sustainable alternative such as a nonprofit self-driven organisation. 
In 1974, 33 years before the UN statement by the Tokyo Ainu group, a similar demand for a community centre was made by Tokyo Ainu. Watson describes that Ainu activist Shizue Ukaji and other members of the Tokyo Utari Association conducted the first survey on Tokyo Ainu, officially entitled Survey of the Socio-economic Conditions of Ainu Residents in Tokyo between 1974-1975 (Watson 2014b: 73). It was funded by the Tokyo Metropolitan Government (Watson 2014b: 73-74). He states that this survey had three purposes:

1. to determine the size of the Ainu population in the capital region;

2. to clarify the problems Ainu faced with a focus on employment, income, culture, education, marriage, and housing;

3. to use these findings to acquire special financial measures and support from the Tokyo Government in order to establish a seikatsukan (community center) for Ainu in the city (ibid.).

It is therefore worth noting that the Tokyo Ainu had been demanding exactly the same things for 33 years.

Overall, it is obvious that the Ainu are in need of a periodical nationwide survey to obtain further understanding of Ainu in general in Japan. In order to gain an overview of the social and economic conditions of the Ainu in Japan, the survey should include Ainu living outside Hokkaidō. Tokyo Ainu are in need of a more autonomous institution, like a community centre, where we can be in charge. If the Japanese Government met this fundamental need, it would imply that they recognise Tokyo Ainu's existence as an Indigenous people with collective rights to self-determination in an urban context. The community centre could be used as a place where we as Tokyo Ainu could share our life experiences and challenges in the process of the further development and restoration of our culture. Here, the most important factor that needs to be supported by the government is the recognition that we as Indigenous people are empowered to manage our projects and set our own agendas. Such a community centre in Tokyo would have a similar role as the kotan (in the Ainu language), which means a village, or place where people live, and where we gather for various activities to share experiences. I perceive this urban kotan as our diaspora. In the next section, I discuss an interpretation of diasporic indigeneity and 'resurgence of Indigenous culture' from my Tokyo Ainu perspective. 


\section{Diasporic indigeneity and everyday acts of resurgence}

As I spent most of my youth in Tokyo, the concept of 'diaspora' is something that is familiar and relevant to my environment and the people I relate to. For example, migrating to cities to seek better employment or commuting from Hokkaidō to Tokyo is considered part of the Ainu urban lifestyle in both Hokkaidō and Tokyo. Our memories of our food, language and culture, and even experiences with family and friends, travel with us wherever we go, and eventually become part of our identities.

So then, what do Tokyo Ainu carry with us in Tokyo? In my experience, we live just like Wajin in Tokyo-wearing modern clothing, eating Japanese food, and so on. Our life is very much integrated into modern Japanese society. The difference is how and when we practise Ainu culture in Tokyo, and how we carry ourselves as Ainu individuals.

First, we still carry our Ainu food culture with us, especially whenever we are able to get hold of ingredients from Hokkaidō. Unfortunately, from Tokyo we cannot easily go to the mountains to harvest the ingredients we need to make Ainu food, or collect bark from trees to make the Ainu traditional robe called attus. All those materials and ingredients are only available in Hokkaidō.

Second, our way of being Ainu needs to be initiated individually. Since we live like Wajin in Tokyo, our consciousness and way of understanding the world is what distinguishes Ainu from non-Ainu persons. Thus, Tokyo Ainu need to be creative about how they use urban space in order to hold traditional ceremonies for special occasions, such as a marriage, or how they will conduct a ceremony for the opening of a new restaurant. Nevertheless, the Ainu Culture Center is used daily by Tokyo Ainu for various activities, like song and dance lessons or for doing embroidery. So, in a way, we still share many cultural practices, just like Hokkaidō Ainu, by using urban space and place to practise and revitalise Ainu culture.

Interpretations of space and place differ in various parts of the world. David Gegeo from the Indigenous groups of Kwara'ae and Lau in the Solomon Islands introduces a more flexible way of understanding such concepts based on his Indigenous background. Gegeo writes: 
Space (kula ni tua, literally, 'place situated in dwell[ing]': that is, place not of one's existential being but rather of temporary or even long-term staying) refers to a space that is not of one's identity or origin. Space has to do with the location where a Kwara'ae person may be at any given time as necessitated by contemporary conditions (such as going to an urban area to get a job to meet basic needs or going overseas in pursuit of an education) (2001: 494).

This approach to 'space' provides a new possibility for us as Indigenous migrants to reroot or relocate ourselves in a new place and environment. What matters is how you position and relate yourself within the environment around you. I share Gegeo's point of view that one can identify with one's place of origin while residing beyond the borders of that place.

Indigenous identities are flexible and changing and reflect, instead of resist, a borderless world. I use and interpret the terminology of Indigenous identity from my Ainu background. For me, Indigenous identity means a way of being myself, the Ainu way-Aynupuri in the Ainu language. Each person has his or her own Ainu way of being, and each person explores his or her world on his or her own terms. Following Gegeo's suggestions concerning how Indigenous people make our own places and spaces in the world, I suggest that we need to work towards a framework where we as Indigenous people can decide our own identities and our position in society without these being externally assigned. In case this extended approach to special relations and Indigenous identity sounds unclear, I will introduce the concept of 'diasporic indigeneity' to support this idea.

Our borderless, urban, westernised contemporary world somehow gives us an impression of living in one big machine with advanced technology, shared customs and sense of being. This entails our rapid mobility and dislocation from our homeland to places where a mainstream culture dominates other cultures. In Tokyo, Ainu culture is not readily visible to the general public. Because of our integration into Japanese society, we are almost invisible. However, our consciousness and identity still remain within us. The term 'diasporic' is therefore a useful term to situate our environment and lived experiences as urban Ainu. 
Mark Watson, who has worked with Tokyo Ainu for many years, explains the major motivation he had for writing his book Japan's Ainu Minority in Tokyo, stating:

This book has been the opportunity to think about how the inherent complexities of Ainu sociality in and around Tokyo intersect with the more general discussion of urban indigeneity as a focus for research at an international level. Diaspora, for example, is a mainstream theoretical concept that contrary to popular opinion is being used by scholars in a variety of ways to describe and better understand the lived experiences of indigenous people outside of traditional lands (2014b: 147).

I very much share his motivation to look into the complexities of Tokyo Ainu sociality, and believe that many of the challenges Tokyo Ainu face in our daily lives are shared by other urban Indigenous people across the globe. The term 'diaspora' has given me a new direction from which to reflect upon our lived experiences as part of an urban Indigenous community. The term 'diaspora' in the context of our borderless urban world is suggestive of Indigenous mobility and the unique characteristics of urban Indigenous conditions, and contains implications for Indigenous understandings of space and place. Living diasporically has become a necessity for many Indigenous people so we can survive and maintain our culture and identity. This new perspective also underlines the importance of urban Indigenous studies in illustrating and explaining the complexity of urban migration for urban Indigenous communities. It also sheds light on the new cultural formation of Indigenous people in cities, something that I have experienced in my youth in Tokyo.

Another example of how this concept has come to life, besides my own experience, is given by Andrea Avaria Saavedra (2005). Saavedra describes how new Indigenous mobilities transform native understandings of space and place. In drawing on a case study of urban Mapuche migration in Chile, Saavedra states:

How do we all live here together, arriving from different places, and with distinct indigenous cultures still intact, within the larger Mapuche whole? Evidence for this new shared identity — with all its social, symbolic and cultural implications-can be found in Mapuche practices, individual experiences, new forms of communication, self-reference and selfdescription. All of these illustrate how the very meaning of being Mapuche can change within the context of an urban and often hostile environment (2005: 54). 
How I interpret Saavedra's analysis of shared identity is that one can still find a shared Indigenous identity through one's experiences, new forms of communication, self-reference and self-description. This supports Watson's (2014b) analysis, presented earlier, about the term 'diasporic indigeneity', which posits that Indigenous people remake their identities in cities through processes of reterrititorialisation, bringing lived relationships with ancestral homelands and community members into the urban context.

This perspective of 'diasporic indigeneity' goes beyond the influential working definition of 'Indigenous' in José R. Martinez Cobo's important Study of the Problem of Discrimination against Indigenous Populations (1987), which emphasises connection with ancestral territories. Although there are no fixed definitions of the concept of 'Indigenous people' within the United Nations' system, Cobo's working definition is internationally recognised and is still widely used. Here, I present two factors relating to the traditional land of Indigenous people summarised by the Secretariat of the Permanent Forum on Indigenous Issues. These two factors specify that: ancestral lands are occupied, or at least of part of them; and that there is shared common ancestry with the original inhabitants of these lands (Secretariat of the Permanent Forum on Indigenous Issues 2004: 2). Cobo's report, which focuses more on ancestral land, highlights how significant social, economic and political changes occurred in Indigenous communities from the 1980s to the present.

In 2018, defining Indigenous people is now even more complex and politicised, and must take into account an ever-expanding variety of political, cultural and economic conditions in various countries around the world. This working definition was provided for practical purposes, but as stated by Saavedra (2005), Indigenous people have come to a point, through globalisation and modernisation, where we are urged to incorporate social relations that extend beyond geographical boundaries. This means that we should examine Indigenous mobility and Indigenous social and cultural expressions on our own terms, which may bring new understandings of the ontological status of Indigenous people.

One may wonder, then, what kind of experiences, new forms of communication, self-reference and self-description from the shared Indigenous identity might be relevant, especially in cities? Jeff Corntassel (2012) in his article, 'Re-envisioning resurgence: Indigenous pathways to decolonisation and sustainable self-determination', discusses the 
concept of Indigenous resurgence, which I find useful in thinking about how Indigenous people construct diasporic indigeneity away from their ancestral homelands. Corntassel explains Indigenous resurgence as people having the bravery and imagination to visualise life beyond the state. He explains:

If one thinks of peoplehood as the interlocking features of language, homeland, ceremonial cycle, and sacred living histories, a disruption to any one of these practices threatens all aspects of everyday life. The complex spiritual, political and social relationships that hold peoplehood together are continuously renewed. These daily acts of renewal, whether through prayer, speaking your language, honouring your ancestors, etc., are the foundation of resurgence (2012: 89).

I share his view and interpretation of 'resurgence', which acknowledges that the various interlocking features of indigeneity are always in flux. Daily acts constitute the foundation of resurgence, and are the substantive content of shared indigeneity based on new forms of communication, self-reference and self-description. Corntassel also emphasises that, within a context of decolonisation practice, it is important to accept daily conditions, and engage oneself with place-based cultural practices (2012: 89). Although I agree with Corntassel in this regard, I think it is important to modulate this place-based emphasis in order to take into account the experience of urban Indigenous people, and look at how acts of resurgence create greater possibilities of new Indigenous pathways in cities. The concept of 'resurgence' can thus be contrasted with Cobo's working definition of indigeneity. Furthermore, if one combines Gegeo's view on the ontological status of Indigenous people, Watson's interpretation of diasporic indigeneities and Corntassel's view on 'everyday acts of resurgence', an important point is clarified-that a person's geographical location does not limit the possibilities of pursuing and developing Indigenous identity and culture.

In the next section, I introduce a detailed case study of the recent historical emergence of Ainu cultural organisations in Tokyo, as an autoethnographic story which touches upon my previous discussion of 'space and place' in relation to an expression of Indigenous identity, diasporic indigeneity and the resurgence of Indigenous culture. 


\section{Rera Cise (the 'House of Wind') in Tokyo}

How one's identity and culture are expressed in society depends on one's relationship to the environment and to other people. To be able to express one's identity and culture, several factors are needed. I roughly categorise these into:

1. people, place and space;

2. food and material objects;

3. rights to decide one's own identities and position in society without them being externally assigned.

As we are collective beings, the connection and association we have with other people, and even material objects, strengthen and determine our motivation and meaning in life regardless of our origins. As discussed earlier, Indigenous people are often forced to move to areas other than our homeland to seek work or education. We often need to adapt ourselves and to associate with others to be able to express our identities and culture in new settings. The concept of everyday acts of resurgence confirms the importance of such acts to the maintenance of identity in an urban setting. To share such a connection and association with others and other things requires us to have a certain place and space where we can exercise our daily routines, rituals and associated activities. As explained earlier, the place and space cannot be traditional land when it comes to an urban Indigenous context. What matters is how we make the most of the place and space available. This is often the reality for urban Indigenous people, where we have no choice other than to make our own present and future in cities. This is what I discussed above as diasporic indigeneity. Lastly, it is most important that we as Indigenous people should have the right to express our culture freely and to define what 'Indigenous culture' is for ourselves, regardless of our geographical location and without external interference. I would now like to bring in my own experiences as a Tokyo Ainu woman to illustrate these concepts.

I identify as Indigenous, mixed Japanese-Ainu. I am a typical urban Ainu, insofar as I did not have the possibility of learning the Ainu language and culture fully, either in school or at home. Thus, my personal learning arena for Ainu culture and the place where I could have a feeling of 'belonging' as part of the Ainu people were spaces, like the Rera Cise restaurant in Tokyo, where I was able to meet other Ainu, including Ainu Elders. 
I was 20 years old when I was introduced to the Ainu restaurant called Rera Cise, and the Ainu Association of Rera, which was an Ainu cultural association established in 1983. Its membership was made up of all Ainu members who worked in or were involved with the Ainu restaurant and other Tokyo Ainu activities. Established in 1994, Rera Cise was the first Ainu restaurant in Tokyo. It was built after a successful national fundraising campaign. Both Japanese and Ainu supporters were involved in the process, which made it possible for Tokyo Ainu to have a place to bring Ainu food culture to Tokyo.

Rera Cise, which literally means 'House of Wind' in the Ainu language, opened in a basement suite in Waseda, Tokyo, opposite Waseda University (Nishi-Waseda campus). It was located in a typical university campus area where many college students passed by every day. The Rera Cise sign was so small that customers could easily miss it. The small entrance to the restaurant may have looked a little mysterious, as there was a long and narrow, dimly lit stairway down to the restaurant. However, when you entered the restaurant, there was, suddenly, quite a different atmosphere.

Ainu music, wooden furniture and cikoro-inaw (Ainu ritual wood-shaving stick) — after having been used for the house ceremony_-decorated the corners of the ceilings for the protection of the space. The restaurant space was quite small, about 50 square metres, with a tiny kitchen only big enough for two people to work together. Despite the location and limited space in the restaurant, many students and teachers came for a cheap, quick, healthy and fulfilling lunch and dinner. Half of the customers were activists and supporters of Rera Cise; the other half were those who had read or heard rumours about the restaurant, and wanted to taste exotic Ainu food. The menu was based on the memories of the Ainu Elders who worked at the restaurant. Some dishes were traditional Ainu food and some were modern food created after the Meiji period (1868-1912). For example, salmon, which was one of the most important staple foods for Ainu, was a much-used ingredient in the menu. A chopped mixture of the salmon head and milt were used to make pickles-citatap in the Ainu language-with roasted seaweed and salt. The head and bones were used as basic bouillon for vegetable soup, which takes two days to make. Salmon eggs were used to make a rice bowl dish called cipor don-rice bowl with salmon eggs (a modern food). The fillet was used for making grilled fish with salt. The fillet was also served as $r u-i-b e-a$ form of frozen sashimi-and it was also dried out with the skin on and served as a snack with beer or sake. 
Ainu practise animism, which is a belief that nonhuman entities (plants, animals and other objects) around human beings possess spiritual essences. Ainu have various names for animals and nature, which are sometimes referred to as Kamuy; the closest term we might use is 'gods', but not in the same sense as the Christian God. Salmon is called Kamuy-cep in the Ainu language and is considered one of the most important of the fish species. An aspect of Ainu philosophy concerning food culture is that Ainu are appreciative of all food they receive from nature. Our use of all parts of the salmon reflects this philosophy. Nature and human beings are equal, and therefore, Ainu live in a sustainable way by sharing all food received by nature, and by leaving some food behind when they have finished hunting for other animals in the mountains.

The Rera Cise restaurant provided space and place for urban Ainu and for those who had an interest in Ainu food and culture, and wanted to share and experience them. It was also a bridge between Elders and youth, where we could transmit our knowledge through various activities. The Ainu Association of Rera, the organisation that ran the restaurant, also had political aims, such as the dissemination and promotion of Ainu culture, and of disseminating political messages, by performing dances and songs at public events, schools and concerts.

I became involved in the Tokyo Ainu community through the Ainu Association of Rera and Rera Cise. I was immediately welcomed and considered to be a member of the Tokyo Ainu community. One reason could be that my grandfather was an Ainu leader and activist who everybody knew. Emotionally speaking, I became very passionate about learning Ainu dances and songs and I appreciated the fact that we could have our own style, voice and expression. As a child, I had been trained very strictly to sing in a Japanese choir where everybody had to be perfectly in tune. In comparison to that experience, the Ainu performance group associated with the Ainu Association of Rera encouraged a much freer style of dancing, to the extent that they looked upon what I thought of as mistakes as expressions of my being a 'knower'-someone who (almost) knew how to dance. On one occasion, the training I received from the Ainu Association of Rera led me to perform as part of a music concert in Ebisu, Tokyo, with professional Indigenous musicians from Japan and Australia (the band from Australia was called Waak Waak Jungi). The most inspiring part of their performance was their mixing of traditional Ainu and contemporary music with the didjeridu, a traditional Australian Aboriginal instrument. The deep, strong sound of the didjeridu created 
a very smooth harmony with the soft and sensitive sounds of the Ainu traditional instrument tonkori, played by the world's most prominent tonkori musician, Oki Kano.

My part involved five minutes of Ainu traditional dancing before the main concert, and I also performed in the chorus together with other female Ainu performers. We rehearsed for several hours, and I was very nervous, especially knowing that the audience had paid a lot of money to attend the concert. There were about 100 people in the audience. The performance took place in the basement of a tall concrete building. I heard the audience whispering to each other before the concert and I became more and more nervous.

Our group dance opened the show. I made a big mistake with my part in the performance. The dance is called fu-ta-re-cui, and expresses the movement of pine trees shaken by a strong wind, so you bend your whole head and upper body to the front and back to express this movement. It is a quite an intense dance and we were all supposed to do the dance movements simultaneously, but I made a mistake by doing it completely opposite to the other performers. I was not able to focus after that. When the show was over, I ran to my dear friend, Takumi Ikabe, a senior Ainu sculptor, with my eyes filled with tears. I said, 'Did you see that I made a big mistake in the group dance!? I feel so ashamed and sad'. He replied, 'Yes, I saw it, but Kanako, that is you. Your mistake is part of you and part of your quality — nothing to be ashamed of'. I was saved by his words. This was unexpected and it surprised me that I was still accepted even with my mistakes. Probably none of my Wajin friends would have said such a thing to me. This perception of accepting whoever you are, with or without mistakes, made me realise how my values were deeply influenced by the Wajin way of thinking, which is that everybody is expected to perform and behave the same as others, without exception. All the pressure and stress I carried with me immediately seemed to evaporate. This sense of being different appealed to me, and not just because it forgave mistakes. I could see that it accepted creativity. This perception of how to look at, interpret, and be in the world made me feel more confident about myself and gave me a chance to think deeply about who I would like to become.

Up until the time I joined the Ainu Association of Rera in Tokyo, Ainu culture had only existed for me in my memories from Hokkaidō, where I spent my childhood with my grandparents. It brought back memories of my struggles to distinguish between two completely different cultures- 
Ainu and Japanese - and I even wondered why I should think and behave differently depending on where I was. I still remember myself as a small child being puzzled by my dual life. Whenever I returned to Tokyo, I acted as a Wajin girl who never talked about Ainu culture. It was not conscious, but, as a child, I quickly realised that no one would understand what I was referring to if I spoke about the Ainu. This continued until I encountered the Tokyo Ainu community. Until then, I would never have imagined that I could find such an Ainu community in the middle of Tokyo. Such a space and social sphere eventually became my emotional home where there is a feeling of 'belonging' and 'home' in my heart.

A dynamic urban space provides different possibilities. It fills an economic need, and it attracts many Indigenous peoples, especially Indigenous youth. It is a space where we can experiment with our future and our possibilities. The anonymous part of city life somehow gives us the freedom to be who we are and who we want to become. Urban life can even provide the flexibility and possibility of having complex identities, and allow us to negotiate those identities and find ways to express ourselves that are most comfortable for us. I agree with Watson's description of how Tokyo has become a new geographical place since the 1960s (2014b: 70). For the Tokyo Ainu, it represents the possibility of reflecting upon one's sense of self, despite all the hardships related to our living and negotiating the political conditions in Tokyo.

My Ainu identity in my early 20s was confirmed and strengthened by associating with other Ainu friends and in social spaces such as Rera Cise in Tokyo, without being in my so-called 'homeland'. Such social spaces became something that symbolised my Ainu culture and became a transformative space for me. They helped me to identify myself as an Indigenous person. The curiosity that grew created many opportunities for me to visit and study overseas. Such overseas experiences, together with the collective recognition from others, have triggered my Indigenous identity and made me proud to be an Ainu. The experiences I have had due to my involvement with Rera Cise support the argument that one's geographical location does not necessarily determine one's identity and culture. Rather, it is through relationships to people and places that experiences are constructed through food culture, language, rituals and ceremonies. These are everyday acts of resurgence in diasporic indigeneity. 
Finally, when we consider what cities can offer Indigenous people in terms of practical solutions, or agonise over what urban Indigenous people can do to improve our situations, it is critically important that Indigenous people are included in all decision-making by legitimising their participation in all related matters. This could support Indigenous people to decide our own identity and our position in society without this being externally assigned. I would like to introduce Gerald Taiaiake Alfred's suggestion of five measurements or guidelines to fulfil Indigenous regeneration for both individuals and communities:

1. The restoration of Indigenous presence on the land and the revitalisation of land-based practices;

2. An increased reliance on traditional diets among Indigenous people;

3. The transmission of Indigenous culture, spiritual teachings and knowledge of the land between Elders and youth;

4. The strengthening of familial activities and re-emergence of Indigenous cultural and social institutions as governing authorities within First Nations; and,

5. Short-term and long-term initiatives and improvements in sustainable land-based economies as the primary economies of reserve based First Nations communities and as supplemental economies for urban Indigenous communities (2009: 56).

I would argue that measurements 2 to 5 are quite suitable for Tokyo Ainu. All of these points manifest the idea that it is of critical importance for us, as Indigenous people, to have our own place and space to regenerate a flow of Indigenous cultural development, especially through a bridge between Elders and youth, regardless of geographic location. For Indigenous people, to eat a traditional diet brings back all the memories and food habits, and the communication that takes place during the process of making food. Eating traditional food constitutes an 'everyday act of resurgence'. To transmit Indigenous culture, spiritual teachings and knowledge of the land between Elders and youth is obviously important. However, what could be added here from an urban perspective is to teach Indigenous youth about alternative ways of expressing one's identity beyond geographical boundaries, and also to provide strategies for relating to the land or homeland without actually being on the land or in the homeland. Strengthening familiar activities and the reemergence of Indigenous cultural and social institutions as governing authorities 
could, of course, raise more awareness among Indigenous people and could reinforce their shared identity. This approach could particularly strengthen the Tokyo Ainu community for two reasons:

1. focusing on collective activities could be more effective since we are prone to organising ourselves and thinking collectively;

2. paying more attention to the reemergence of Indigenous cultural and social institutions could reaffirm that we are as important as political and economic institutions.

Short-term and long-term initiatives and improvements in sustainable land-based economies for providing supplemental economies for urban Indigenous communities could also be relevant in many ways.

A place like Rera Cise was capable of supporting most of the elements mentioned above. It was the place where a traditional diet was revitalised, where Ainu culture, language and spirituality were transmitted across generations, and most importantly, it was a cultural and social institution which was independently run by the Ainu. The role of the cultural and social institution of course helped to inform political activities as well. It led to the translation of political messages that were conveyed to Japanese society-voicing our claims as well as describing future possibilities. Rera Cise became the place for everybody to gather together with youth and Elders, to eat Ainu food, to discuss the future and to share Ainu culture. It was definitely a central Ainu organisation in Tokyo from 1994 to 2009. A small urban space like Rera Cise can thus be a foundation for resurgence, where it produces Indigenous knowledge through food, music, art and interactions between Elders and youth. It creates a 'home' where it is possible to feel free to express one's sense of being with both Indigenous and non-Indigenous people.

\section{Conclusion}

I consider myself a Tokyo Ainu, yet I fully acknowledge my complex identity as someone who grew up in Japanese society just like any other Wajin. What I consider 'home' is where I have an emotional attachment and through which some of my 'being as Ainu' was formed. For example, Nibutani Village, one of the Ainu sacred places of Hokkaidō, where I spent all my school holidays with my grandparents and cousins, is 'home', as is that particular time and place in Tokyo when I became Ainu 
with the Ainu community there. But, what does this tell us about how resurgence is intertwined with urban Indigenous life? My memories and experiences are embedded in my body, which influences my daily actions and behaviour, wherever I am. I cannot deny the fact that I am part of the huge machinery of globalisation, and that globalisation has given me so many opportunities to explore the world. All these years of living abroad and in cities has raised a question of how I can position myself and find my own Indigenous pathway as an Ainu person, regardless of geographical location and without being actually at 'home'. It is true that all the memories are embedded in my body, but these memories need to be performed and activated to be able to be part of my real life. What has been helpful for me to reconnect myself to the Ainu culture is to play mukkuri (the Ainu traditional mouth harp), which can be played alone, and anywhere in the world. Singing Ainu songs, which I learned from my time in Tokyo, also helps me to reconnect myself to Ainu culture. However, what seems to be most important for me is to be able to share my daily stories and struggles with Ainu friends who accept who I am.

I consider my experiences with the Tokyo Ainu community to consist of many 'everyday acts of resurgence' in a framework of diasporic indigeneity. What we did within the community was to reconnect ourselves with memories from Hokkaidō through food, music, ceremony and even our own consciousness. We revitalised and strengthened our culture and consciousness by securing our urban space and place, without actually being in our 'homeland'. Rera Cise was a good example of such a space and place. It was unique in Tokyo. It fostered our minds to be creative and think critically, and enabled us to explore Ainu culture together. The door of Rera Cise was always open to Wajin or anyone who was interested in Ainu culture. Having such an Ainu-driven urban kotan (community) provided opportunities for the revitalisation of Ainu culture in urban space. Furthermore, it provided an opportunity for both Ainu and nonAinu persons to share and discover Ainu culture and, in the process, even to discover themselves. As we are faced with increasing numbers of Indigenous people migrating to cities in the future, such urban kotan could offer a way to reestablish a better foundation for a more inclusive social model. 


\section{Acknowledgements}

Numbers of experienced scholars and friends from all over the world supported and encouraged me to write this article. First, I wish to thank Tetuhito Oono, who helped me with the Ainu language and Ainu tradition. From Arctic Norway, my supervisors, Torill Nyseth and Torjer Andreas Olsen, as well as Helen Verran from Australia, helped me to conceptualise my life stories in academic discussions. Hiroshi Maruyama from Japan and Gerald Roche, as well as Åsa Virdi Kroik, as editors of the article also followed and supported me throughout the process. Mark Watson from Canada, who is my long-term friend, encouraged me to write about the urban Ainu by introducing me to various related theories and discussions. The Sami scholar from the United States, Troy Storfell, supported me in the last phase of writing the article by providing comments and perspectives of Indigenous studies from North America.

\section{References}

Advisory Council for Future Ainu Policy. 2009. Final Report. Online: www. kantei.go.jp/jp/singi/ainu/dai10/siryou1_en.pdf (accessed 11 July 2018).

Ainu Association of Hokkaidō. 2018. Ainu Historical Events. Online: www.ainuassn.or.jp/english/history.html (accessed 11 July 2018).

Ainu Association of Rera. 2001. Statement by the Ainu Association of Rera Nineteenth Session of the UN Working Group on Indigenous Populations 23-27 July 2001, Geneva. Online: www.geocities.jp/indigenousnet/200119thWGIP statementE.pdf (accessed 2 August 2018).

Ainu minzoku o senjū minzoku to suru koto o motomeru ketsugi [Resolution on Recognition of Ainu as Indigenous People], No. 169th Diet Session, House of Representatives (6 June 2008) and House of Councillors (6 June 2008).

Ainu Resource Centre and Shimin Gaikou Centre. 2007. Situation and Issues of Ainu in the Kanto Region. Online: cendoc.docip.org/collect/cendocdo/index/ assoc/HASH3862/845fd5a8.dir/PF07ainu211.pdf (accessed 12 July 2018).

Alfred, Gerald Taiaiake. 2009. 'Colonialism and state dependency'. International Journal of Indigenous Health 5(2): 42-60. Online: ashbrookclassroom. pbworks.com/w/file/fetch/61011895/Colonialism\%20and\%20State\%20 Dependency.pdf (accessed 14 July 2018). 
Cobo, José R. Martinez. 1987. Study of the Problem of Discrimination against Indigenous Populations. E/CN.4/Sub.2/1986/7 Add. 4. United Nations. Online: undocs.org/en/E/CN.4/Sub.2/1986/7/Add.4 (accessed 24 July 2018).

Corntassel, Jeff. 2012. 'Re-envisioning resurgence: Indigenous pathways to decolonization and sustainable self-determination'. Decolonization: Indigeneity, Education \& Society 1(1): 86-101. Online: jps.library.utoronto.ca/ index.php/des/article/view/18627 (accessed 14 July 2018).

Council for Ainu Policy Promotion Working Group on the Ainu Living Conditions outside of Hokkaidō Survey. 2011. The Report of the Working Group on the Ainu Living Conditions outside of Hokkaido Survey. Online: www.kantei.go.jp/jp/ singi/ainusuishin/dai3/siryou3_3.pdf (accessed 11 July 2018).

Department of Hokkaidō Environment and Lifestyle. 2017. The Report of Hokkaidō Ainu Living Conditions Survey. Online: www.pref.hokkaido.lg.jp/ ks/ass/H29_ainu_living_conditions_survey.pdf (accessed 12 August 2018).

Gegeo, David Welchman. 2001. 'Cultural Rupture and Indigeneity: The Challenge of (Re)visioning "Place" in the Pacific'. The Contemporary Pacific 13(2): 491-507. doi.org/10.1353/cp.2001.0052

Hokkaidō Former Natives Protection Act, promulgated (北海道旧土人保護法 公布) by the Meiji Government, 2 March 1899 (Meiji 32).

Promotion of the Ainu Culture and for the Dissemination and Advocacy for the Traditions of the Ainu and the Ainu Culture (Law No. 52, 14 May 1997; Amendment: Law No. 160, 22 December 1999).

Saavedra, Avaria Andrea. 2005. 'Mobile identity: The Mapuche of Santiago, Chile'. In Indigenous Diasporas and Dislocations, edited by Graham Harvey and Charles D. Thompson Jr, 53-60. London: Routledge.

Secretariat of the Permanent Forum on Indigenous Issues. 2004. The Concept of Indigenous Peoples. PFII/2004/WS.1/3. United Nations. Online: www. un.org/esa/socdev/unpfii/documents/workshop_data_background.doc (accessed 14 July 2018).

Siddle, Richard. 1996. 'Former natives'. In Race, Resistance and the Ainu of Japan, 51-75. London: Routledge.

The Foundation for Research and Promotion of Ainu Culture. 2018. History of the Foundation's Establishment. Online: www.frpac.or.jp/web/english/details/ history-of-the-foundations-establishment.html (accessed 8 August 2018). 
United Nations Declaration on the Rights of Indigenous Peoples, GA Res 61/295, UN GAOR, 61st sess, 107th plen mtg, Sup No 49, UN Doc A/RES/61/295 (13 September 2007).

United Nations Department of Economic and Social Affairs. 2014. World Urbanization Prospects: The 2014 Revision. ST/ESASER.A/352, New York: United Nations. Online: esa.un.org/unpd/wup/publications/files/wup2014highlights.pdf (accessed 12 July 2018).

Watson, Mark. 2014a. 'Tokyo Ainu and the urban Indigenous experience'. In Beyond Ainu Studies: Changing Academic and Public Perspectives, edited by Mark J. Hudson, Ann-Elise Lewallen and Mark K. Watson, 69-85. University of Hawai'i Press.

Watson, Mark. 2014b. Japan's Ainu Minority in Tokyo: Diasporic Indigeneity and Urban Politics. London and New York: Routledge. doi.org/10.4324/ 9781315815435

Whitinui, Paul. 2014. 'Indigenous autoethnography: Exploring, engaging, and experiencing "self" as a Native method of inquiry'. Journal of Contemporary Ethnography 43(4): 456-87. doi.org/10.1177/0891241613508148 
This text is taken from Indigenous Efflorescence: Beyond Revitalisation in Sapmi and Ainu Mosir, edited by Gerald Roche, Hiroshi Maruyama and Åsa Virdi Kroik, published 2018 by ANU Press, The Australian National University, Canberra, Australia.

doi.org/10.22459/IE.2018.20 